\title{
Constructing a Scientific and Multidimensional Quality Evaluation Mechanism for Ideological and Political Education in Colleges and Universities
}

\author{
Jingguan Qin*, Shaowei Zhou \\ School of Marxism, Weinan Normal University, Weinan 714099, Shaanxi Province, China \\ *Corresponding author: Jingguan Qin, 1044238127@qq.com
}

\begin{abstract}
The construction of curriculum ideological and political education mechanism in colleges and universities in China has begun to take effect. In view of the differences in the key points of different colleges and universities in the construction of curriculum ideological and political education mechanism, the quality evaluation of curriculum ideological and political education mechanism is particularly important. However, the quality evaluation mechanism is related to ability, fairness, and potential. It is essential to assume the effectiveness of moral education in college curriculum ideological and political education as the benchmark, adhere to positioning experts, teachers, and students as the key elements of the main body of the evaluation mechanism, as well as establish a diversified quality evaluation standard system based on the teaching management, infrastructure, and moral education effectiveness. Building a scientific and multi-dimensional quality evaluation mechanism for ideological and political education in colleges and universities would promote the connotative development of ideological and political education in courses.
\end{abstract}

Keywords: Curriculum ideological and political education; Quality evaluation mechanism; Evaluation index system; Effectiveness of moral education

Publication date: November 2021; Online publication: November 30, 2021

\section{Introduction}

The construction of curriculum ideology and politics in colleges and universities is the need of the times, the demand of majors, and the preparation of talents. It is not only a systematic project related to the development of colleges and universities, but also a quality project affecting the development orientation of professional disciplines ${ }^{[1]}$. Colleges and universities need to enhance their initiative to participate in its construction, clarify their responsibility, establish a hierarchical guidance and management system, coordinate and mobilize multi-party participation, as well as increase the power source of collaborative education. In addition, a quality evaluation system of curriculum ideological and political collaborative education should be established, and a scientific and multi-dimensional quality evaluation mechanism should be built from three dimensions: assume the effectiveness of moral education as the benchmark, position experts, teachers, and students as the evaluation members, and establish a diversified quality evaluation standard system. It is essential to put forward scientific and reasonable quality evaluation standards to provide a reference for ideological and political teaching reform of different disciplines ${ }^{[2]}$.

\section{Assuming the effectiveness of moral education as the benchmark of quality evaluation mechanism} Building morality and cultivating people are the fundamental tasks of educational development in colleges and universities. The effectiveness of moral education is an important reference index to measure the degree 
of implementing these fundamental tasks in colleges and universities. The construction of a quality evaluation mechanism aims to take the effectiveness of moral education as the standard of evaluating education quality. It is necessary to eliminate the traditional epistemological evaluation standard of education quality and take the effectiveness of moral education as the benchmark of the evaluation mechanism.

Therefore, in constructing the evaluation mechanism for curriculum ideological and political education, the effectiveness of moral education should be adhered as the benchmark. At the same time, under the fundamental standards, corresponding supporting evaluation criteria should be established to supplement and improve it. The supporting evaluation standards can be formulated according to different levels and types of schools, different professional courses, and different types of teachers. In order to ensure an accurate data support, the establishment of a differentiated teaching quality evaluation mechanism in curriculum ideological and political education is objectively required. The mechanism should be a systematic, hierarchical, scientific, and diverse teaching quality evaluation mechanism of ideological and political education in courses directly under the Ministry of Education, which is independent of a single university. Taking the national basic standards as the bottom line, a differentiated teaching quality evaluation system should be established to evaluate the quality of the construction of ideological and political education mechanism in colleges and universities. Evaluation reports should be written, and work results should be regularly published on the official websites of universities. In the construction process of the quality evaluation system, optimize and deepen the use of various types of data acquisition methods, which can be carried out from three aspects.

The first is to formulate a unique quality evaluation mechanism for curriculum ideological and political education at different levels and types of schools. It is necessary to comprehensively analyze the schools' development strength, teaching resources, and the focus of their development. It is also important to adhere to the principle of seeking truth from facts, comprehensively consider the development needs of the schools and the development strength it can provide, as well as formulate differentiated evaluation standards. Second, on the basis of adhering to the concept of "building morality and cultivating people," different professional courses have different degrees of ideological and political education. It is necessary to respect the professional characteristics of professional courses and investigate the degree of integrating "educational elements" into the knowledge system of different professional courses, so as to determine the effectiveness of education. Finally, the work types and focus of different teachers vary. Some teachers focus on academic research or scientific research, while for others, their focus is on implementing the fundamental tasks of building morality and cultivating people in the teaching process. Therefore, different types of teachers cannot investigate the effect of curriculum ideological and political education according to unified standards, but appropriate quality evaluation standards should be formulated based on different types of teachers.

\section{Experts, teachers, and students are the key elements of quality evaluation}

In order to ensure the comprehensiveness and fairness of the quality evaluation of curriculum ideological and political education mechanism, it would be beneficial to expand the members participating in the evaluation, form an evaluation team with experts, teachers, and students as elements, as well as enhance the accuracy of the quality evaluation.

\subsection{Focusing on the quality evaluation of ideological and political education mechanism by members of the expert group}

When evaluating the quality of the curriculum ideological and political education mechanism, each 
university should form a team of experts in this field. The team members can come from different universities or even absorbed from research institutes, so as to form a high-level quality evaluation expert group to evaluate the construction of the curriculum ideological and political education mechanism in detail as a whole systematically, so as to determine the existing problems and make amendments in time. The expert group can implement the regular review and evaluation system for the quality evaluation and properly evaluate the quality according to the construction progress of the curriculum ideological and political education mechanism of different schools. This provides a guarantee for promoting the construction of the curriculum ideological and political education mechanism and improving its quality.

\subsection{Teachers are the key to the construction of curriculum ideological and political education mechanism}

Professional course teachers are the main body of curriculum ideological and political construction ${ }^{[3]}$. Therefore, they should play their role in the construction of the quality evaluation of curriculum ideological and political education mechanism. As front-line workers of curriculum ideological and political education, teachers have a deeper understanding and experience of certain relevant policies, training programs, students' learning, etc. Therefore, if teachers are included as evaluation members, the evaluation of the quality of the curriculum ideological and political education mechanism would be more comprehensive and detailed. It is necessary to sort out and analyze the teachers"' understanding, views, and experience on the construction of the curriculum ideological and political education mechanism as well as the self-evaluation of education and teaching, which can also be used as the source of quality evaluation reference standards.

\subsection{Paying attention to students' feedback on the learning effect of ideological and political teaching}

In the course of ideological and political education, the feedback on the learning effect of students is an important reference standard to judge the quality of the constructed mechanism. As the audience in the teaching reform of curriculum ideological and political education, the students' expectations, sense of acquisition, and participation are extremely important in the quality evaluation of curriculum ideological and political education. Therefore, it is necessary to begin implementing the student feedback system, master a large amount of information in teaching, test the effect of the construction of the mechanism from the group of audience, combine the data analysis of the teaching quality supervision and evaluation system, realize the organic combination of the evaluation subjects at different levels in space, as well as obtain a more authentic and convincing conclusion. Other than that, it is important to provide information and basis for adjusting the construction of curriculum ideological and political education mechanism, promote the continuous promotion of teaching management through the effective implementation of the system, and finally improve the quality of college curriculum ideological and political education.

\section{Establishing a quality evaluation index system of ideological and political education in diversified courses}

The construction of curriculum ideological and political education mechanism involves many aspects. Therefore, when evaluating the quality of curriculum ideological and political education, multiple evaluation indexes should be determined, and a diversified evaluation index system should be established, in order to ensure the accuracy and fairness of the quality evaluation.

\subsection{The teaching management status of curriculum ideological and political education mechanism}

The teaching management status of ideological and political education mechanism in colleges and universities reflects the education quality of the mechanism to a large extent. The teaching management of 
the curriculum ideological and political education mechanism is the key link to deal with the cooperation between various parts and jointly promote the construction its mechanism. In order to evaluate the quality of ideological and political education from the teaching management status, the contents of teaching management in the curriculum ideological and political education mechanism should be clarified, such as the teaching training plan, teaching objectives, teaching methods, and teaching means. These contents should be assumed as an important basis for judging the state of the teaching management, so as to make an accurate judgment on the teaching management of the curriculum ideological and political education mechanism as well as to take this judgment as an important index in the quality evaluation system.

\subsection{The basic construction degree of curriculum ideological and political education mechanism}

The degree of perfection and the role of the system in the teaching process of curriculum ideological and political education should be taken as the main contents of investigation in relevant institutional infrastructure of the curriculum ideological and political education mechanism, including the standardized guidance, organization and implementation, as well as the coordination of the relationship between various parts of the construction of the mechanism. The construction of platforms related to the curriculum ideological and political education mechanism in infrastructure construction, such as experience exchange platform, exchange learning platform, as well as collective teaching and research platform, can effectively improve teachers' ability in curriculum ideological and political education. The teaching consciousness and ability of teachers in curriculum ideological and political education are important parameters to measure the quality of curriculum ideological and political education. Therefore, the basic construction degree of curriculum ideological and political education mechanism should be a part of the quality evaluation system of diversified curriculum ideological and political education.

\subsection{Effectiveness of moral education in curriculum ideological and political education}

The effectiveness of moral education in curriculum ideological and political education is mainly reflected in the learning effect of students in the teaching of curriculum ideological and political education. Specifically, the learning effect of the students is reflected in their interest in the course, their acceptance of ideological and political theories, their understanding of socialist core values, and the cultivation of correct values, outlook on life, and world outlook. In the process of considering the effect of moral education, these contents should be taken as the focus of evaluating the effect of moral education. In evaluating the effectiveness of moral education in curriculum ideological and political education, it is necessary to focus on the evaluation of the effectiveness of moral education effect in professional curriculum ideological and political education. At the same time, the leading role of ideological and political education evaluation in curriculum ideological and political education should not be neglected.

\section{Disclosure statement}

The authors declare that there is no conflict of interest.

\section{References}

[1] Zhou L, 2021, Research on Innovative Ideas of Curriculum Ideological and Political Construction in Colleges and Universities in the New Era. Educational Theory and Practice, 41(27): 34-36.

[2] Shi W, Zhang H, 2020, On the Quality Standards of Ideological and Political Teaching in Colleges and Universities. China Higher Education, (17): 36-38. 
[3] He R, Chen L, 2021, An Analysis of the Way to Improve the Ideological and Political Ability of College Professional Teachers. School Party Construction and Ideological Education, (18): 63-65. 